Article

\title{
Optimization for Liquid-Liquid Extraction of Cd(II) over Cu(II) Ions from Aqueous Solutions Using Ionic Liquid Aliquat 336 with Tributyl Phosphate
}

\author{
Lai Yee Lee $\mathbb{D}$, Norhashimah Morad, Norli Ismail, Amir Talebi and Mohd Rafatullah *(D) \\ School of Industrial Technology, Universiti Sains Malaysia, Gelugor 11800, Penang, Malaysia; \\ lly15_tec003@student.usm.my (L.Y.L.); nhashima@usm.my (N.M.); norlii@usm.my (N.I.); \\ amirtalebi@usm.my (A.T.) \\ * Correspondence: mrafatullah@usm.my; Tel.: +60-4653-2111; Fax: +60-4653-6375
}

Received: 18 August 2020; Accepted: 14 September 2020; Published: 18 September 2020

check for updates

\begin{abstract}
This study investigates the separation of two heavy metals, $\mathrm{Cd}(\mathrm{II})$ and $\mathrm{Cu}(\mathrm{II})$, from the mixed synthetic feed using a liquid-liquid extraction. The current study uses tri-octyl methylammonium chloride (Aliquat 336) as the extractant (with tributyl phosphate (TBP) as a phase modifier), diluted in toluene, in order to investigate the selective extraction of $\mathrm{Cd}(\mathrm{II})$ over $\mathrm{Cu}$ (II) ions. We investigate the use of ethylenediaminetetraacetic acid (EDTA) as a masking agent for $\mathrm{Cu}(\mathrm{II})$, when added in aqueous feed, for the selective extraction of $\mathrm{Cd}(\mathrm{II})$. Five factors that influence the selective extraction of $\mathrm{Cd}(\mathrm{II})$ over $\mathrm{Cu}(\mathrm{II})$ (the equilibrium $\mathrm{pH}\left(\mathrm{pH}_{\mathrm{eq}}\right.$ ), Aliquat 336 concentration (Aliquat 336), TBP concentration (TBP), EDTA concentration (EDTA), and organic to aqueous ratio (O:A)) were analyzed. Results from a $2^{5-1}$ fractional factorial design show that Aliquat 336 significantly influenced $\mathrm{Cd}(\mathrm{II})$ extraction, whereas EDTA was statistically significant for the antagonistic effect on the $\mathrm{E} \%$ of $\mathrm{Cu}$ (II) in the same system. Moreover, results from optimization experiment showed that the optimum conditions are Aliquat 336 concentration of $99.64 \mathrm{mM}$ and EDTA concentration of $48.86 \mathrm{mM}$ - where $95.89 \%$ of $\mathrm{Cd}$ (II) was extracted with the least extracted $\mathrm{Cu}$ (II) of $0.59 \%$. A second-order model was fitted for optimization of $\mathrm{Cd}$ (II) extraction with a $\mathrm{R}^{2}$ value of 0.998 , and ANOVA results revealed that the model adequately fitted the data at a 5\% significance level. Interaction between Aliquat 336 and $\mathrm{Cd}(\mathrm{II})$ has been proven via FTIR qualitative analysis, whereas the addition of TBP does not affect the extraction mechanism.
\end{abstract}

Keywords: heavy metal separation; ionic liquid; extraction; masking agent; liquid-liquid extraction; selective extraction

\section{Introduction}

Stringent environmental regulations and depletion of the world's mineral resources have urged for the removal and recovery of heavy metals from the metallurgical production and hydrometallurgical processing waste and secondary sources in complex leach solutions. Despite their toxicity, $\mathrm{Cd}$ and $\mathrm{Cu}$ are used in industries, such as metal refining, mining, electroplating, and manufacturing of alloys. Cd is often found in industrial waste by-products, such as $\mathrm{Cd}$-rich dust, $\mathrm{Cu}-\mathrm{Cd}$ slag, and hydrometallurgical leachates, along with other heavy metals, e.g., $\mathrm{Cu}, \mathrm{Ni}, \mathrm{Zn}$, etc. [1]. Selective separation and recovery of $\mathrm{Cd}$ from wastewater containing various metallic constituents can be achieved by chemical precipitation, adsorption, ion exchange, solvent extraction, electrolysis, etc. [2]. Different metal species with almost identical valence configurations in the same mixture allows co-transport, and it makes selective extraction a tough challenge. Selective extraction of $\mathrm{Cd}(\mathrm{II})$ is feasible in the presence of $\mathrm{Zn}(\mathrm{II}), \mathrm{Ni}(\mathrm{II})$, $\mathrm{Co}(\mathrm{II}), \mathrm{Mn}(\mathrm{II}), \mathrm{Fe}(\mathrm{II}), \mathrm{Ca}(\mathrm{II})$, and $\mathrm{Mg}$ (II), but $\mathrm{Cu}(\mathrm{II})$ and $\mathrm{Pb}$ (II) were found to be co-extracted with 
$\mathrm{Cd}(\mathrm{II})$ [3]. The presence of $\mathrm{Cd}$ in the same mixture was found to interrupt the physiological balance of other metals [4].

Liquid-liquid extraction (LLE) is one of the most versatile techniques used for the selective separation, recovery, and purification of aqueous media containing metal ions [5]. LLE is a simple and quick method with low operational cost [6]. LLE utilizes the principle of analyte (metal cation) distribution ratios between two immiscible liquids (generally consist of one organic and one aqueous phase) in contact with each other to achieve separation. The separation of metal within a multi-element mixture is known as selectivity. To justify the efficiency of LLE in selective separation of one metal over the other metal, the distribution ratios and separation factors of metals using selected extractant are used by most researchers [7,8]. Several studies have been reported in the literature on different combinations of organic extractants have been intensively investigated for the extraction of $\mathrm{Cd}$ (II) from synthetic solutions, industrial wastewaters, and complex leach solutions. Organophosphorus-based extractants, such as di-(2-ethylhexyl) phosphoric acid (D2EHPA), 2-ethylhexyl phosphonic acid mono-2-ethylhexyl ester (PC88A), and di-2,4,4-trimethylpentyl phosphinic acid (Cyanex 272), were used to extract of $\mathrm{Cd}(\mathrm{II})$ from synthetic sulfate solutions by cation exchange mechanism [9]. Free fatty acid-rich oil derived from palm kernel distillate had been introduced for $\mathrm{Cu}(\mathrm{II})$ extraction, as green and renewable extractants without the need of diluent for its low melting point, low density, low water solubility, and moderate viscosity [10]. However, the new fatty acid has not been tested with the separation of other metals, and its selectivity for other metals is not specified. Ionic liquids (IL) are known as task-specific extractants and have been highlighted in various scientific publications for their improved and adjustable physicochemical properties, such as thermal stability, high polarity, negligible vapor pressure, non-flammability, and wide range of miscibility with other organic solvents [11,12]. Quaternary ammonium-based IL, such as tri-octyl methylammonium chloride (Aliquat 336), and phosphonium-based IL, e.g., trihexyl(tetradecyl)phosphonium chloride (Cyphos IL101), were used to extract Cd(II) [13]. Rapid extraction equilibria were achieved, where 99\% of Cd(II) ions were extracted using 0.2 M Aliquat 336 and 0.04 M Cyphos IL101 in kerosene, respectively. Trihexyl(tetradecyl)phosphonium bis(2,4,4-trimethylpentyl) phosphinate (Cyphos IL 104) was used for separation of $\mathrm{Cd}(\mathrm{II})$ over $\mathrm{Cu}(\mathrm{II}), \mathrm{Co}(\mathrm{II})$ and $\mathrm{Ni}(\mathrm{II})$ and the separation factors were found in order of $\mathrm{S}_{\mathrm{Cd} / \mathrm{Cu}}<\mathrm{S}_{\mathrm{Cd} / \mathrm{Co}}<\mathrm{S}_{\mathrm{Cd} / \mathrm{Ni}}[14]$.

Neutral extracting agents like tributyl phosphate (TBP) and trioctylphosphine oxide (TOPO) have high extraction coefficients for many metals and organic solutions, but low selectivity when used as sole extractant. TBP has been discovered to control third-phase formation, as a phase modifier. D2EHPA-TBP has been proven for the improved extraction of several metal cations, such as $\mathrm{Cu}$ (II) $[15,16], \mathrm{Co}(\mathrm{II})[17,18], \mathrm{Fe}(\mathrm{III})$ [19], Ni(II) [20], $\mathrm{Zn}$ (II) [21]. There is no literature traceable regarding the extraction of $\mathrm{Cd}(\mathrm{II})$ using the combination of Aliquat 336 and TBP. Application of masking agent enhances the selective separation of metal ions by means to suppress the interference of unwanted constituents in a system without forming elaborate separation. Masking agents are also metal-complexing agents, introduced to improve the separation factor in the extraction procedures. Separation factor of Cd(II) over Zn(II) was increased by more than 500 times using D2EHPA as extractant and an aqueous hexadentate ligand with nitrogen donors, $N, N, N^{\prime}, N^{\prime}$-tetrakis(2-pyridylmethyl)ethylene diamine (TPEN) as a masking agent for Zn(II) [22]. Ethylenediaminetetraacetic acid (EDTA) has been proved as the most useful masking agent, by forming anionic complexes with several metal ions. EDTA acted as a masking agent in the source phase for $\mathrm{Fe}(\mathrm{III}), \mathrm{Cu}(\mathrm{II}), \mathrm{Ni}(\mathrm{II})$, and $\mathrm{Zn}(\mathrm{II})$ during the selective permeation of uranium using sodium carbonate as the receiving phase [23]. 0.1 M EDTA was added into ammonia buffer at the stripping phase at a ratio of 4 to 1 to separate Cd(II) from $\mathrm{Zn}$ (II) and $\mathrm{Ni}(\mathrm{II})$ [13].

The investigation of the capability of Aliquat 336-TBP in extracting Cd(II) and the efficiency of EDTA in suppressing the co-extraction of $\mathrm{Cu}$ (II) has not been reported in the literature. The current work aims to find out the selective extraction of $\mathrm{Cd}$ (II) over $\mathrm{Cu}$ (II) ions by using Aliquat 336 (extractant) with TBP (phase modifier) and EDTA as a masking agent. Various process variables affecting the 
extraction were studied and optimized using response surface methodology (RSM). RSM has been proven to be an effective statistical tool to evaluate the interaction between variables [24,25]. In this study, the two-level fractional factorial design was used for screening experiments, whereas central composite design was used for the optimization of significant parameters. Analysis of the second-order model was conducted to achieve the optimum response. Qualitative Fourier transform infrared (FTIR) measurement was recorded on the extractant and their combination to compare the change of bonds in the organic phase after extraction.

\section{Materials and Methods}

\subsection{Chemicals and Reagents}

Copper sulfate pentahydrate $\left(\mathrm{CuSO}_{4} \cdot 5 \mathrm{H}_{2} \mathrm{O}\right)(\geq 99.6 \%$ purity) and cadmium sulfate hydrate $\left(\mathrm{CdSO}_{4} \cdot \mathrm{H}_{2} \mathrm{O}\right)(\geq 98 \%$ purity) were obtained from Merck. The organic extractants used to extract the metal ion were TBP ( $\geq 99 \%$ purity), and Aliquat 336 ( $\geq 95 \%$ purity) from Sigma-Aldrich. The dilution of organic extractant was performed using commercial toluene purchased from Sigma-Aldrich.

Nitric acid $\left(\mathrm{HNO}_{3}\right)(\geq 65 \%)$, sulfuric acid $\left(\mathrm{H}_{2} \mathrm{SO}_{4}\right)(\geq 98 \%)$, ethylenediaminetetraacetic acid (EDTA) $(\geq 98 \%)$, sodium hydroxide $(\mathrm{NaOH})(\geq 99 \%)$ and sodium sulfate $\left(\mathrm{Na}_{2} \mathrm{SO}_{4}\right)(\geq 99 \%)$ were purchased from Merck. Glassware was cleansed with Decon 90 and washed before soaking in $5 \% \mathrm{HNO}_{3}$. Deionized water was used for final washing of glassware and to prepare all the aqueous mixtures.

\subsection{Equipment}

Aqueous and organic phases were mixed using a digital overhead stirrer (IKA, Microstar 7.5 control). Initial and final equilibrium $\mathrm{pH}\left(\mathrm{pH}_{\mathrm{eq}}\right)$ readings of aqueous phase were measured by $\mathrm{pH}$ meter (Sension+ pH3, Hach, Loveland CO, USA). The Cd(II) and $\mathrm{Cu}$ (II) ions concentration before and after extraction studies were analyzed separately using a flame atomic absorption spectrophotometer (FAAS) (AA-7000, Shimadzu, Tokyo, Japan) after appropriate filtration and dilution. Air-acetylene $\left(\right.$ Air- $\left.\mathrm{C}_{2} \mathrm{H}_{2}\right)$ flame of $2300{ }^{\circ} \mathrm{C}$ was used for atomization of all samples. Analyses of $\mathrm{Cd}(\mathrm{II})$ and $\mathrm{Cu}$ (II) were conducted, based on Table 1.

Table 1. Standard conditions for $\mathrm{Cd}(\mathrm{II})$ and $\mathrm{Cu}(\mathrm{II})$ analysis.

\begin{tabular}{ccc}
\hline Conditions & Cd(II) & Cu(II) \\
\hline Wavelength $(\mathrm{nm})$ & 228.8 & 324.8 \\
Background correction with $\mathrm{D}_{2}$ lamp $(1 \%$ absorbance in $\mathrm{ppm})$ & $0.007-0.015$ & $0.02-0.04$ \\
$\mathrm{C}_{2} \mathrm{H}_{2}$ flow rate $(\mathrm{L} / \mathrm{min})$ & 1.8 & 1.8 \\
$\mathrm{LOD}(\mathrm{ppm})$ & $0.002-0.008$ & $0.006-0.02$ \\
LOB $(\mathrm{ppm})$ & $0.0005-0.0007$ & $0.0014-0.0019$ \\
LOQ $(\mathrm{ppm})$ & $0.007-0.03$ & $0.02-0.08$ \\
\hline
\end{tabular}

FTIR spectrometer (FrontierTM, Perkin Elmer, MA, USA) with universal attenuated total reflectance polarization (FTIR-ATR) was operated in the mid-infrared region with wavenumbers spanning from about $600 \mathrm{~cm}^{-1}$ to $4000 \mathrm{~cm}^{-1}$ for investigation of infrared spectra of the organic phase before and after extraction.

\subsection{Preparation of Aqueous and Organic Mixtures}

The aqueous mixture was prepared from $\mathrm{CdSO}_{4} \cdot \mathrm{H}_{2} \mathrm{O}$ and $\mathrm{CuSO}_{4} \cdot 5 \mathrm{H}_{2} \mathrm{O}$ with $200 \mathrm{mM} \mathrm{Na} \mathrm{SO}_{4}$ as inert salt in deionized water. Various concentrations of EDTA (10 mM to $100 \mathrm{mM})$ were added to the aqueous solution, as a masking agent. The organic mixture was prepared with Aliquat 336 as extractant, TBP or TOPO as phase modifier, and toluene as diluent. Different concentrations of Aliquat 336 (50-200 mM) and phase modifier (0-100 mM) were tested. TBP and TOPO were used as phase modifier to reduce the formation of emulsion and enhancement of phase separation during LLE. 
Karl-Fischer determination for fresh Aliquat 336 had been identified to have $1.7 \mathrm{wt} \%$ water, and toluene had $0.03 \mathrm{wt} \%$ water. Due to a small amount of Aliquat 336 added into toluene (as diluent) utilized in this experiment, the water content in the mixture of Aliquat 336 in toluene was not significant.

\subsection{Selective Liquid-Liquid Extraction of $\mathrm{Cd}(\mathrm{II})$ and $\mathrm{Cu}(\mathrm{II})$ Ions}

Extraction studies were conducted by combining $20 \mathrm{~mL}$ of the organic mixture (Aliquat 336 and TBP) with the aqueous mixture $(100 \mathrm{mg} / \mathrm{L} \mathrm{Cd}(\mathrm{II})$ and $\mathrm{Cu}(\mathrm{II})$ ions) at a ratio of $1: 1$. The mixture was stirred with an overhead stirrer at $150 \mathrm{rpm}$ for $10 \mathrm{~min}$ and left to separate for $5 \mathrm{~min}$. The $\mathrm{pH}_{\mathrm{eq}}$ of the aqueous mixture was recorded before adjusting to preferable $\mathrm{pH}$ by adding in small drops of $\mathrm{H}_{2} \mathrm{SO}_{4}$ or $\mathrm{NaOH}$. The mixture was mixed again and left to separate for 5 min until the desired $\mathrm{pH}_{\mathrm{eq}}$ was obtained. To collect the separated aqueous sample, an aqueous phase containing extracted metals was obtained after phase disengagement using a separating funnel. The separated aqueous samples were analyzed to determine the concentrations of metal contents, $M_{\mathrm{aq}}$ of $\mathrm{Cu}(\mathrm{II})$ and $\mathrm{Cd}(\mathrm{II})$, respectively, with FAAS after appropriate dilution.

Standard error was found to be less than $1 \%$ after triplicate runs of the experiment. The percentage of extraction (E\%) of metal ions was calculated using Equation (1).

$$
\text { Extraction, } \mathrm{E}(\%)=\frac{\left[M_{\mathrm{i}}\right]-\left[M_{\mathrm{aq}}\right]}{\left[M_{\mathrm{i}}\right]} \times 100
$$

where $M_{\mathrm{i}}(\mathrm{mg} / \mathrm{L})$ is the initial metal ion concentration in aqueous phase, and $M_{\mathrm{aq}}(\mathrm{mg} / \mathrm{L})$ is the final metal ion concentration after LLE studies.

\subsection{Screening and Optimization of Operating Parameters}

In this study, response surface methodology (RSM) was used for analytical optimization of variables that govern the selective extraction of $\mathrm{Cd}$ (II) over $\mathrm{Cu}$ (II) ions significantly. All experiments were run in triplicate, and the relative standard deviation between replicated samples was less than $2 \%$. Minitab software (Release 17, Minitab Inc., State College, PA, USA) was used to analyze the data involved in RSM. A $2^{5-1}$ fractional factorial design was applied to screen five important parameters within their specific ranges, namelym equilibrium $\mathrm{pH}(\mathrm{pH} 2-5)$, Aliquat 336 concentration Aliquat 336 (50-100 mM), TBP concentration TBP (50-100 mM), concentration of EDTA (10-50 mM), and organic to aqueous ratio (O:A) (1:1 to 2:1) for their significance on the response (E\%). Other factors, such as mixing time $(10 \mathrm{~min})$, operating temperature $\left(28 \pm 1^{\circ} \mathrm{C}\right)$, mixing speed $(150 \mathrm{rpm})$, concentration of inert salt $\mathrm{Na}_{2} \mathrm{SO}_{4}(200 \mathrm{mM})$, initial concentration of $\mathrm{Cd}$ (II) and $\mathrm{Cu}(\mathrm{II})$ ions $M_{\mathrm{i}}(100 \mathrm{mg} / \mathrm{L})$, diluent type (toluene) were fixed at specific values, based on earlier findings. Sixteen experimental runs were conducted for each metal whereby the range for each parameter was determined based on the earlier findings $[26,27]$.

The optimization experiment was studied using central composite design (CCD) on selective extraction of $\mathrm{Cd}(\mathrm{II})$ over $\mathrm{Cu}(\mathrm{II})$ ions obtained from the screening experiments. Level 0 represents the center value of each parameter, the low $(-1)$ and high $(+1)$ values, the extreme low $(-\alpha)$ values, and the extreme high $(\alpha)$ values for each parameter studied [28]. Parameters that did not have a significant impact on the selective extraction of $\mathrm{Cd}(\mathrm{II})$ over $\mathrm{Cu}(\mathrm{II})$, were fixed at low values. Other parameters were fixed as described in screening experiments. The optimum operating conditions for maximum $\mathrm{Cd}(\mathrm{II})$ separation from $\mathrm{Cu}$ (II) using Aliquat 336-TBP in toluene with EDTA were evaluated by Minitab software. Composite desirability $(D)$ was used to evaluate the optimum value of significant parameters by identifying the degree of satisfaction. 
A second-order response function in Equation (2) was selected to best fit the response data for multiple regression analysis:

$$
y=\beta_{o}+\sum_{i=1}^{k} \beta_{i} x_{i}+\sum_{i=1}^{k} \beta_{i i} x_{i}^{2}+\sum \sum_{j<i} \beta_{i j} x_{i} x_{j}+\varepsilon
$$

where $y$ is the dependent variable, $\beta_{0}, \beta_{i}, \beta_{i i}$ and $\beta_{i j}$ are the regression coefficients of intercept, linear, quadratic, and interaction variables, respectively, $x_{i}$ and $x_{j}$ are the independent variables, and $\varepsilon$ is the error for the effects of excluded parameters. By using Minitab software, the coefficients gathered from optimization experiments, were determined by the least square's method [28] to best fit the regression model.

\section{Results and Discussion}

\subsection{Effect of $\mathrm{pH}$ on the Extraction of $\mathrm{Cd}(\mathrm{II})$ and $\mathrm{Cu}(\mathrm{II})$ Ions}

The operating range of $\mathrm{pH}$ in the feed solution determines the rate of transportation of $\mathrm{Cd}(\mathrm{II})$ and $\mathrm{Cu}$ (II) ions. Extraction had proven to be low at alkaline $\mathrm{pH}$, due to the formation of insoluble metal hydroxide with the appearance of $\mathrm{OH}^{-}$ions in the aqueous mixture and unsuccessful complexation with the extractant [29]. Hence, this study was performed with an aqueous solution with a $\mathrm{pH}$ from 2.0 to 5.5. To separate $\mathrm{Cd}$ from $\mathrm{Cu}$, experiments were conducted by using a single carrier, Aliquat 336 in toluene, and different combinations of the carrier with phase modifiers, such as Aliquat 336-TBP and Aliquat 336-TOPO, as shown in Figure 1.

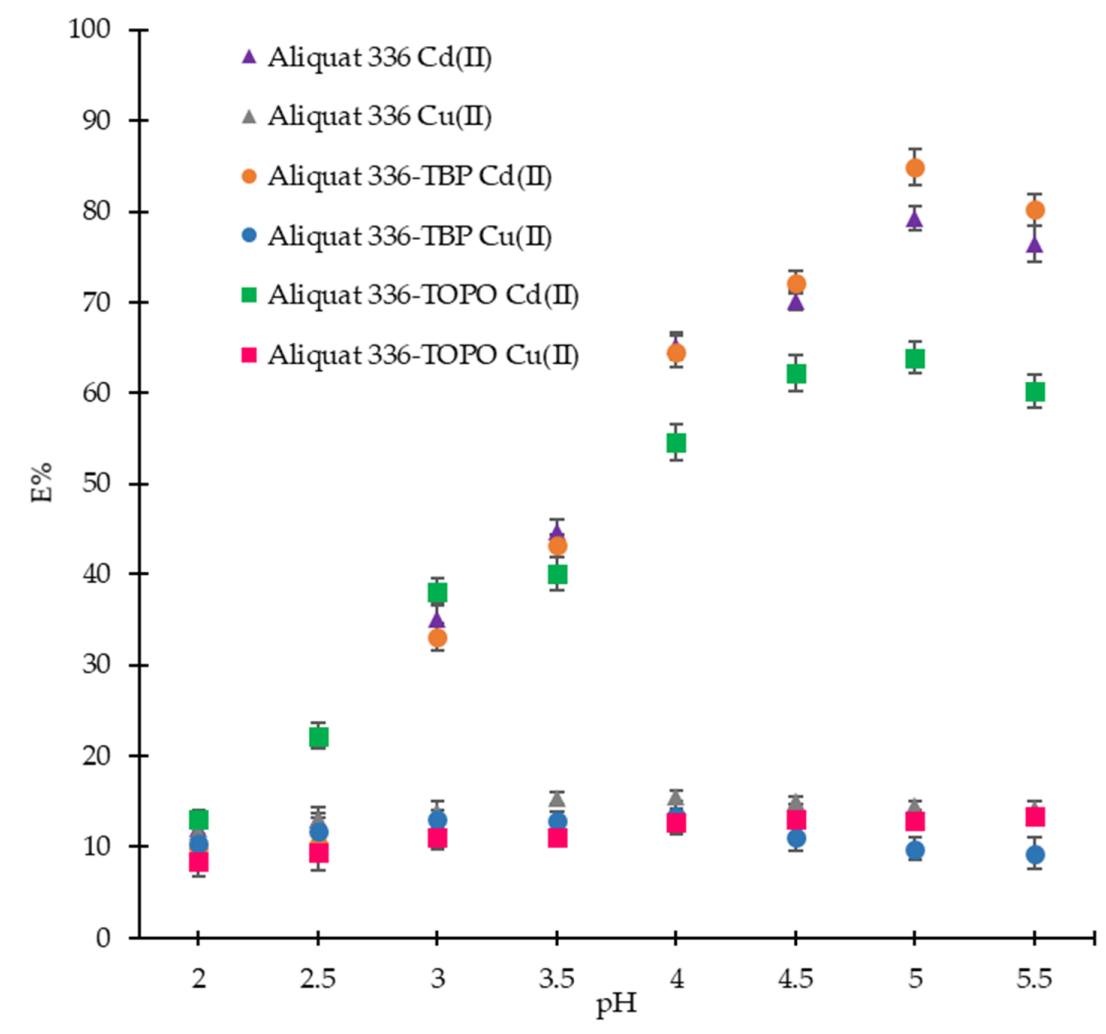

Figure 1. Effect of $\mathrm{pH}$ on the extraction of $\mathrm{Cd}(\mathrm{II})$ and $\mathrm{Cu}(\mathrm{II})$ ions using Aliquat 336 and combinations of Aliquat 336 with TBP and TOPO (mixing time: 10 min; operating temperature: $28 \pm 1^{\circ} \mathrm{C}$; mixing speed: $150 \mathrm{rpm} ; \mathrm{Na}_{2} \mathrm{SO}_{4}: 200 \mathrm{mM}$; diluent: toluene; $M_{\mathrm{i}}: 100 \mathrm{mg} / \mathrm{L} ; \mathrm{O}:$ A ratio = 1:1; Aliquat 336: $100 \mathrm{mM}$; TBP: $50 \mathrm{mM}$; TOPO: $50 \mathrm{mM}$ ). 
The influence of the addition of $50 \mathrm{mM}$ phase modifier (TBP or TOPO) into $100 \mathrm{mM}$ Aliquat 336 on the separation of $\mathrm{Cd}(\mathrm{II})$ and $\mathrm{Cu}$ (II) ions (initial concentration for both metal ions was $100 \mathrm{mg} / \mathrm{L}$ ) with the change in $\mathrm{pH}$ feed was also examined. Other factors, such as mixing time (10 min), operating temperature $\left(28 \pm 1^{\circ} \mathrm{C}\right)$, mixing speed $(150 \mathrm{rpm})$, concentration of sodium sulfate $\mathrm{Na}_{2} \mathrm{SO}_{4}(200 \mathrm{mM})$, and diluent type (toluene) were fixed. The results indicated that the addition of TOPO into Aliquat 336 did not improve the extraction efficiency as compared with Aliquat 336 as a single extractant whereas, Aliquat 336 with TBP in toluene intensified the extraction of Cd(II) over $\mathrm{Cu}$ (II) ions at pH 4.5 and more. $100 \mathrm{mM}$ Aliquat 336 and $50 \mathrm{mM}$ TBP enhanced the extraction by having the maximum extraction of $\mathrm{Cd}(\mathrm{II})(84.93 \%)$ with the least extracted $\mathrm{Cu}(\mathrm{II})(9.79 \%)$ at $\mathrm{pH} 5$. In previous literature, $\mathrm{Cd}(\mathrm{II})$ transport efficiency was $82 \%$ when only $100 \mathrm{mM}$ Aliquat 336 was used as the sole extractant [26]. Combinations of extractants with TBP had also been proven to improve separation efficiency and phase separation [16,30].

\subsection{Effect of Carrier Concentration}

The effect of concentration of extractant (Aliquat 336) on the separation of $\mathrm{Cd}(\mathrm{II})$ and $\mathrm{Cu}(\mathrm{II})$ had also been studied. Concentrations of Aliquat 336 in the range of $50 \mathrm{mM}$ to $200 \mathrm{mM}$ were investigated. The obtained results are shown in Figure 2. As observed when $100 \mathrm{mM}$ of Aliquat 336 in toluene was used, the extraction of $\mathrm{Cd}$ (II) ions is almost two times more effective than when $50 \mathrm{mM}$ was used. It may be explained by considering the increasing availability and formation of $\mathrm{Cd}(\mathrm{II})$-Aliquat 336 complex. For extraction of Cd(II) with Aliquat 336, Cd(II) extended its coordination numbers and tended to connect to $\mathrm{Cl}$ attached on Aliquat 336. Extraction equilibrium of $\mathrm{Cd}$ (II) from sulfate mixture by $\mathrm{R}_{4} \mathrm{~N}-\mathrm{Cl}$ can be expressed in the Equation (3). Thus, $\left(\mathrm{R}_{4} \mathrm{~N}-\mathrm{Cl}\right)_{2} \cdot \mathrm{CdSO}_{4}$ is the main extracted complex.

$$
\mathrm{Cd}^{2+}+\mathrm{H}_{2} \mathrm{SO}_{4}+2 \mathrm{R}_{4} \mathrm{~N}-\mathrm{Cl} \leftrightarrow \mathrm{CdSO}_{4} \cdot 2 \mathrm{R}_{4} \mathrm{~N}-\mathrm{Cl}+2 \mathrm{H}^{+}
$$

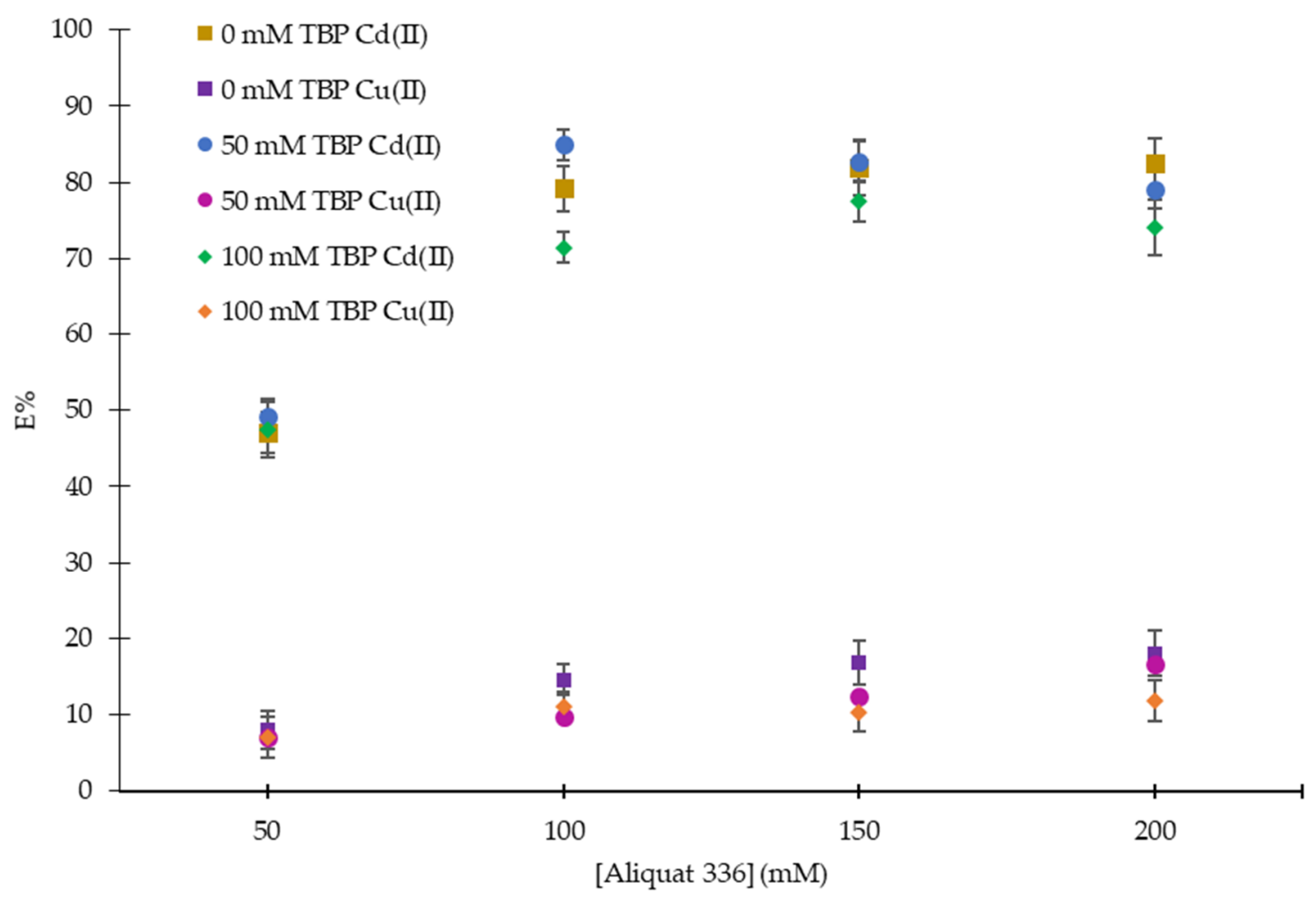

Figure 2. Effect of Aliquat 336 concentration on the extraction of $\mathrm{Cd}(\mathrm{II})$ and $\mathrm{Cu}(\mathrm{II})$ ions (mixing time: $10 \mathrm{~min}$; operating temperature: $28 \pm 1^{\circ} \mathrm{C}$; mixing speed: $150 \mathrm{rpm}$; $\mathrm{Na}_{2} \mathrm{SO}_{4}: 200 \mathrm{mM}$; diluent: toluene; $M_{\mathrm{i}}: 100 \mathrm{mg} / \mathrm{L} ; \mathrm{pH}_{\mathrm{eq}}: 5 ; \mathrm{O}: \mathrm{A}$ ratio $\left.=1: 1\right)$. 
This also shows that Aliquat 336 dissolves satisfactorily in toluene. Results also showed that a further increase in Aliquat 336 concentration after $100 \mathrm{mM}$ did not improve the extraction much. Excess carrier concentration ( $150 \mathrm{mM}$ to $200 \mathrm{mM}$ ) eventually increased the viscosity of the membrane phase, resulting in the reduced mobility and lowered diffusion rate of the metal-carrier complex [28].

Results obtained from Figures 1 and 2 confirmed that the combination of Aliquat 336 with $50 \mathrm{mM}$ TBP is more efficient in the separation of $\mathrm{Cd}$ (II) over $\mathrm{Cu}$ (II) ions. Without TBP, the extraction of $\mathrm{Cu}$ (II) was observed to increase from $8 \%$ to $18 \%$ as the concentration of Aliquat 336 was increased from $50 \mathrm{mM}$ to $200 \mathrm{mM}$. However, a further increase in the concentration of TBP up to $100 \mathrm{mM}$ reduced the extraction of $\mathrm{Cd}(\mathrm{II})$ as the viscosity of the organic phase increased.

\subsection{Effect of EDTA as a Masking Agent}

At $\mathrm{pH} 5,100 \mathrm{mM}$ Aliquat 336 and $50 \mathrm{mM}$ TBP had proven to extract $\sim 85 \%$ of Cd(II) with the least extracted $\mathrm{Cu}(\mathrm{II})$. However, $\sim 10 \%$ of $\mathrm{Cu}$ (II) were co-transported along with $\mathrm{Cd}(\mathrm{II})$, and it was difficult to separate $\mathrm{Cu}$ (II) from $\mathrm{Cd}$ (II) completely. To enhance the separation of $\mathrm{Cd}$ (II) over $\mathrm{Cu}(\mathrm{II})$, masking agents were introduced to suppress the interference of a particular metal from involving in the reaction without the need of another separation. In current work, EDTA was used as a masking agent to suppress $\mathrm{Cu}$ (II) from forming extractable complexes and to improve the selectivity of $\mathrm{Cd}$ (II) ions. Concentrations of 10 to $100 \mathrm{mM}$ of EDTA were used to investigate the masking efficiencies of EDTA towards the transport of $\mathrm{Cd}(\mathrm{II})$ and $\mathrm{Cu}(\mathrm{II})$. Results in Figure 3 showed that the increased EDTA concentration reduced the co-extraction of $\mathrm{Cu}$ (II) without reducing the transport efficiency of $\mathrm{Cd}(\mathrm{II})$. $50 \mathrm{mM}$ EDTA attained the highest extraction of $\mathrm{Cd}$ (II) $(76.43 \%)$ with $\mathrm{Cu}(\mathrm{II})$ almost negligible $(0.59 \%)$. $\mathrm{Cu}(\mathrm{II})$ ions were proven to be masked by $50 \mathrm{mM}$ EDTA in the extraction studies using $100 \mathrm{mM}$ Aliquat 336 with $50 \mathrm{mM}$ TBP at pH 5 . However, the extraction of Cd(II) decreased by $26 \%$ when $100 \mathrm{mM}$ EDTA was used. The solubility of EDTA was reduced when its concentration increased by more than $50 \mathrm{mM}$. It can be suggested that EDTA concentration affects the separation of $\mathrm{Cd}$ (II) and $\mathrm{Cu}$ (II) through the solubility of the masking agent in the medium and the mobility of the metal-complex in the membrane liquid.

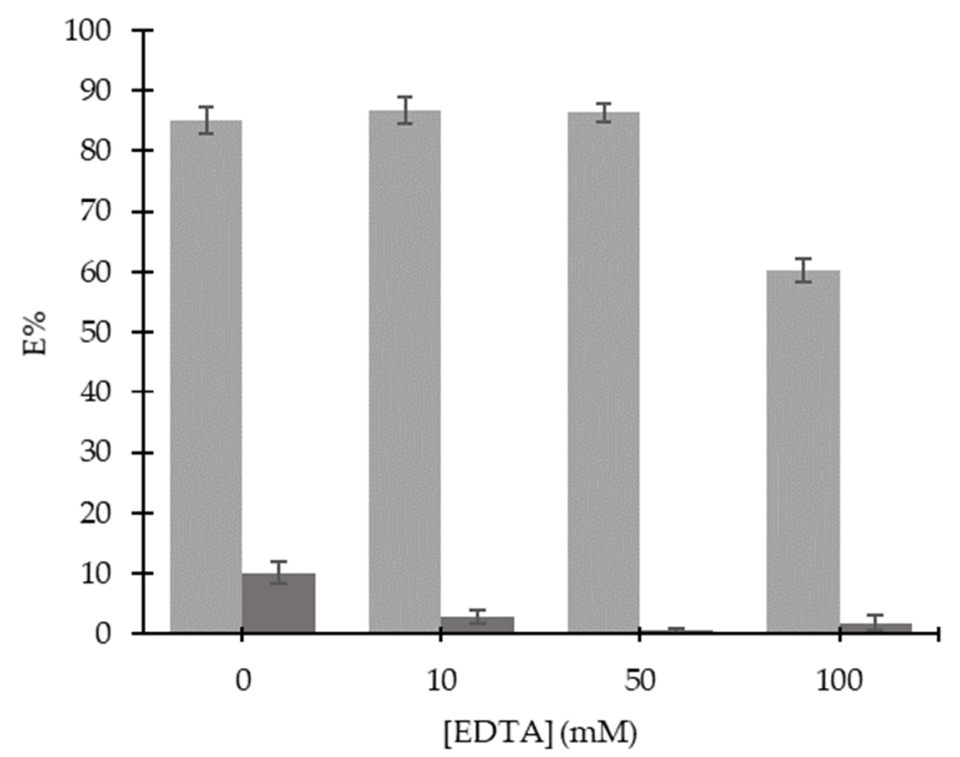

Figure 3. Effect of ethylenediaminetetraacetic acid (EDTA) on the extraction of $\mathrm{Cd}(\mathrm{II})$ and $\mathrm{Cu}(\mathrm{II})$ ions (Aliquat 336: $100 \mathrm{mM}$; TBP: $50 \mathrm{mM}$; diluent: toluene; mixing time: $10 \mathrm{~min}$; operating temperature: $28 \pm 1^{\circ} \mathrm{C}$; mixing speed: $150 \mathrm{rpm} ; M_{\mathrm{i}}: 100 \mathrm{mg} / \mathrm{L} ; \mathrm{pH}_{\mathrm{eq}}: 5$; O:A ratio = 1:1). 
3.4. Screening of Parameters Affecting the Extraction of Cd(II) and Cu(II) Metal Ions Using $2^{5-1}$ Fractional Factorial Design

A total of 16 runs in the design matrix for $2^{5-1}$ fractional factorial design as in Table 2, along with the average $\mathrm{E} \%$, were measured in triplicate to screen the factors affecting the extraction of $\mathrm{Cd}$ (II) and $\mathrm{Cu}$ (II) using Aliquat 336 (extractant), TBP (phase modifier) and EDTA (masking agent). The experimental runs (Std Order) were randomized to reduce the effects of uncontrollable factors. The extraction of $\mathrm{Cd}$ (II) was found to range from 8.97 to $89.25 \%$. These factors were evaluated using a probability plot (Figure $4 \mathrm{a}$ ) at a $5 \%$ significance level. Based on the analysis in Figure $4 \mathrm{a}$, significant effects that emerge from the normal probability plot are the main effects of $\mathrm{A}(\mathrm{pH})$ and $\mathrm{B}$ (Aliquat 336). Concentration of Aliquat 336 was found to influence the extraction of $\mathrm{Cd}(\mathrm{II})$ more significantly than the aqueous feed $\mathrm{pH}$. An increase in the concentration of Aliquat 336 resulted in an increase in Cd(II) transport rate, due to a higher amount of free Aliquat 336. At $50 \mathrm{mM}$ to $100 \mathrm{mM}$ of Aliquat 336, the feed/membrane interface was not fully saturated, indicating that the rise in the concentration of extractant could increase the $\mathrm{Cd}(\mathrm{II})$ transport efficiency. Aqueous feed $\mathrm{pH}$ in this study plays a minor role in the extraction of Cd(II). However, Nayl [31] had proven that separation of divalent metals by increasing the aqueous feed $\mathrm{pH}$ by different forms of Aliquat 336. Thus, the best $\mathrm{pH}$ for selective extraction of $\mathrm{Cd}(\mathrm{II})$ over $\mathrm{Cu}$ (II) is fixed at $\mathrm{pH} 5$.

Table 2. Screening using $2^{5-1}$ fractional factorial design and average $\mathrm{E} \%$ of $\mathrm{Cd}(\mathrm{II})$ and $\mathrm{Cu}(\mathrm{II})$ using Aliquat 336 and TBP in toluene and EDTA as masking agent; diluent: toluene; operating temperature: $28 \pm 1^{\circ} \mathrm{C}$; mixing speed: $150 \mathrm{rpm}$; Cd: $100 \mathrm{mg} / \mathrm{L} ; \mathrm{Cu}: 100 \mathrm{mg} / \mathrm{L}$.

\begin{tabular}{|c|c|c|c|c|c|c|c|c|}
\hline \multirow{2}{*}{ Std Order } & \multirow{2}{*}{ Run Order } & \multirow{2}{*}{$\mathrm{pH}$} & \multirow{2}{*}{ Aliquat 336} & \multirow{2}{*}{ TBP } & \multirow{2}{*}{ EDT } & \multirow{2}{*}{ O:A } & \multicolumn{2}{|c|}{ Average E\% } \\
\hline & & & & & & & Cd(II) & $\mathrm{Cu}(\mathrm{II})$ \\
\hline 5 & 1 & 2 & 50 & 100 & 10 & 1:01 & $9.53 \pm 0.43$ & $10.97 \pm 0.77$ \\
\hline 8 & 2 & 5 & 100 & 100 & 10 & 1:01 & $69.04 \pm 1.78$ & $6.11 \pm 0.35$ \\
\hline 3 & 3 & 2 & 100 & 50 & 10 & 1:01 & $14.49 \pm 1.09$ & $11.02 \pm 0.92$ \\
\hline 6 & 4 & 5 & 50 & 100 & 10 & 2:01 & $56.77 \pm 1.97$ & $6.26 \pm 0.33$ \\
\hline 16 & 5 & 5 & 100 & 100 & 50 & 2:01 & $78.53 \pm 1.62$ & $1.73 \pm 0.21$ \\
\hline 10 & 6 & 5 & 50 & 50 & 50 & 2:01 & $70.12 \pm 1.54$ & $1.65 \pm 0.43$ \\
\hline 9 & 7 & 2 & 50 & 50 & 50 & 1:01 & $8.97 \pm 0.94$ & $9.46 \pm 0.65$ \\
\hline 14 & 8 & 5 & 50 & 100 & 50 & 1:01 & $29.73 \pm 1.12$ & $4.61 \pm 0.58$ \\
\hline 13 & 9 & 2 & 50 & 100 & 50 & 2:01 & $10.66 \pm 0.93$ & $8.34 \pm 0.49$ \\
\hline 2 & 10 & 5 & 50 & 50 & 10 & $1: 01$ & $52.05 \pm 1.84$ & $7.32 \pm 0.31$ \\
\hline 1 & 11 & 2 & 50 & 50 & 10 & 2:01 & $9.19 \pm 0.71$ & $10.76 \pm 0.81$ \\
\hline 7 & 12 & 2 & 100 & 100 & 10 & 2:01 & $10.48 \pm 0.89$ & $12.02 \pm 0.95$ \\
\hline 15 & 13 & 2 & 100 & 100 & 50 & 1:01 & $12.09 \pm 0.52$ & $5.58 \pm 0.22$ \\
\hline 4 & 14 & 5 & 100 & 50 & 10 & 2:01 & $89.25 \pm 1.91$ & $7.44 \pm 0.36$ \\
\hline 11 & 15 & 2 & 100 & 50 & 50 & 2:01 & $20.98 \pm 0.71$ & $7.93 \pm 0.51$ \\
\hline 12 & 16 & 5 & 100 & 50 & 50 & 1:01 & $84.93 \pm 1.12$ & $1.08 \pm 0.18$ \\
\hline
\end{tabular}

Table 2 also showed the factors affecting the extraction of $\mathrm{Cu}(\mathrm{II})$, whereby 16 experimental runs were randomized, and the average $\mathrm{E} \%$ of $\mathrm{Cu}(\mathrm{II})$ was found at $1.08 \%$ to $12.02 \%$ using the same experimental design for extraction of $\mathrm{Cd}(\mathrm{II})$. Figure $4 \mathrm{~b}$ showed the main effects of the factors that affect $\mathrm{E} \%$ of $\mathrm{Cu}(\mathrm{II})$, and their interactions were also examined using a normal probability plot. It was found that D (EDTA) is the only influential parameter affecting $\mathrm{Cu}$ (II) extraction. However, the increase in the concentration of EDTA lowered the $\mathrm{Cu}(\mathrm{II})$ transport efficiency significantly. Hence, this could be attributed to the masking effect of EDTA towards the extraction of $\mathrm{Cu}$ (II) using Aliquat 336 with TBP. 

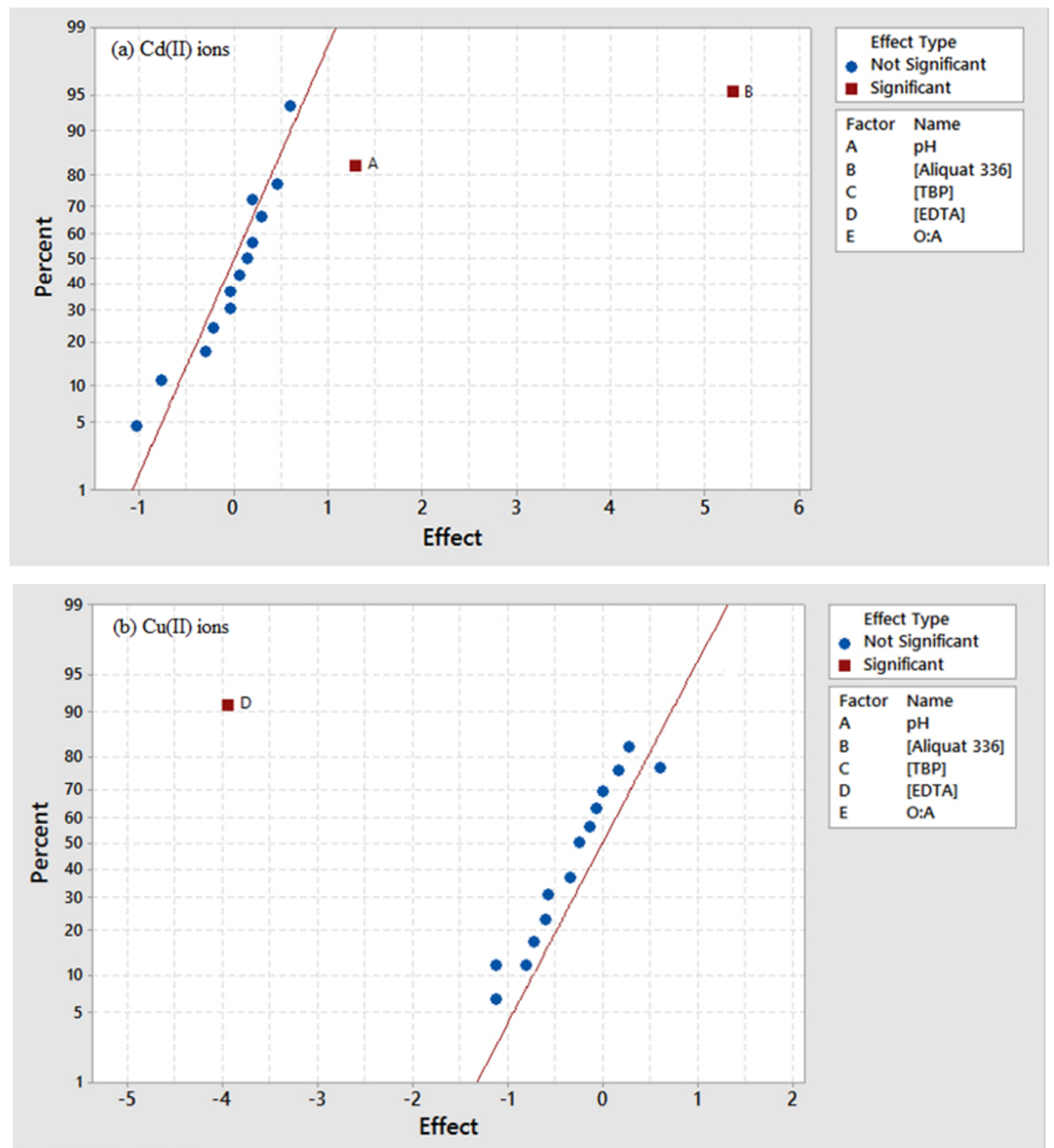

Figure 4. Normal probability plots for (a) extraction of $\mathrm{Cd}(\mathrm{II})$ ions and (b) extraction of $\mathrm{Cu}(\mathrm{II})$ ions.

\subsection{Optimization of Cd(II) Ions Extraction Using Aliquat 336-TBP in Toluene}

\subsubsection{Optimization Using Central Composite Design (CCD)}

It is noteworthy that two factors, Aliquat 336 and EDTA, have proven to influence the selective extraction of $\mathrm{Cd}$ (II) over $\mathrm{Cu}$ (II) significantly. Optimization using CCD where each factor was studied in five levels, as shown in Table 3. The factors ranged from 39.65 to $110.35 \mathrm{mM}$ for Aliquat 336 and from 1.72 to $58.28 \mathrm{mM}$ for EDTA. Other controlled factors, such as aqueous feed $\mathrm{pH}(\mathrm{pH} 5)$, diluent type (toluene), concentration of $\mathrm{Cd}$ and $\mathrm{Cu}$ in feed phase $(100 \mathrm{mg} / \mathrm{L})$, mixing speed $(150 \mathrm{rpm})$, temperature $\left(28 \pm 1{ }^{\circ} \mathrm{C}\right)$, mixing time (10mins), O:A ratio (1:1), and TBP $(50 \mathrm{mM})$, were fixed.

Table 3. Five different levels of parameters examined for optimization using CCD.

\begin{tabular}{cccccccc}
\hline \multirow{2}{*}{ Parameters } & \multirow{2}{*}{ Symbols } & \multirow{2}{*}{ Units } & \multicolumn{5}{c}{ Levels } \\
\cline { 4 - 8 } & & & $-\boldsymbol{\alpha}$ & $\mathbf{- 1}$ & $\mathbf{0}$ & $\mathbf{+ 1}$ & $\mathbf{+ \alpha}$ \\
\hline Aliquat 336 & $\mathrm{B}$ & $\mathrm{mM}$ & 39.65 & 50 & 75 & 100 & 110.35 \\
EDTA & $\mathrm{D}$ & $\mathrm{mM}$ & 1.72 & 10 & 30 & 50 & 58.28 \\
\hline
\end{tabular}

Based on 13 experimental runs, the data were used to develop a regression model that correlates $\mathrm{E} \%$ (response) with the factors, and their adequacies were determined. The best-operating conditions 
of factors for maximum extraction of $\mathrm{Cd}(\mathrm{II})$ were determined, continued by evaluation of their degree of satisfaction. Table 4 shows the design matrix and results of CCD with two factors (D2EHPA (B) and EDTA (D) and one response (extraction\%) to extract Cd. The extraction of Cd(II) was found to range from 60.06 to $96.19 \%$.

Table 4. Central composite design for optimization of $\mathrm{Cd}(\mathrm{II})$ ions extraction (diluent: toluene; mixing time: $10 \mathrm{~min}$; operating temperature: $28 \pm 1^{\circ} \mathrm{C}$; $\mathrm{TBP}: 50 \mathrm{mM}$; mixing speed: $150 \mathrm{rpm} ; M_{\mathrm{i}}: 100 \mathrm{mg} / \mathrm{L} ; \mathrm{pH}_{\mathrm{eq}}: 5$; $\mathrm{O}: \mathrm{A}$ ratio $=1: 1)$.

\begin{tabular}{cccc}
\hline \multirow{2}{*}{ Run } & \multicolumn{2}{c}{ Factors * } & \multirow{2}{*}{ Extraction\% } \\
\cline { 2 - 3 } & B & D & \\
\hline 1 & 50.00 & 50.00 & $72.92 \pm 1.03$ \\
2 & 110.35 & 30.00 & $94.47 \pm 1.98$ \\
3 & 75.00 & 30.00 & $92.52 \pm 1.83$ \\
4 & 75.00 & 30.00 & $92.48 \pm 1.94$ \\
5 & 75.00 & 30.00 & $92.51 \pm 1.14$ \\
6 & 75.00 & 30.00 & $92.44 \pm 2.09$ \\
7 & 50.00 & 10.00 & $60.18 \pm 1.22$ \\
8 & 75.00 & 58.28 & $88.91 \pm 0.92$ \\
9 & 75.00 & 1.72 & $71.48 \pm 1.05$ \\
10 & 100.00 & 10.00 & $85.91 \pm 1.66$ \\
11 & 100.00 & 50.00 & $96.19 \pm 1.73$ \\
12 & 39.65 & 30.00 & $60.06 \pm 1.81$ \\
13 & 75.00 & 30.00 & $92.49 \pm 1.98$ \\
\hline \multicolumn{3}{c}{ * B: Aliquat 336 (mM); D: EDTA (mM). }
\end{tabular}

\subsubsection{Regression Model and Analysis of Variance for Cd(II) Extraction}

Regression analysis (Table 5) for Cd(II) extraction was performed to find the estimated regression coefficients, along with the corresponding standard deviation $\left(\mathrm{SD}_{\text {coef }}\right)$, t-statistics (t-stat), and $p$-values, for linear, square, and interaction terms of a regression model. The calculate probability, $p$-values were less than 0.05 , indicated all variable terms were statistically significant. Hence, a second-order polynomial model in coded unit that correlates extraction of Cd(II) is described by Equation (4):

$$
\mathrm{E} \%=37.994+2.3481 \mathrm{~B}+1.3097 \mathrm{D}-0.012152 \mathrm{~B} * \mathrm{~B}-0.015325 \mathrm{D} * \mathrm{D}-0.001230 \mathrm{~B} * \mathrm{D}
$$

where B and D are Aliquat 336 and EDTA, respectively. The extent of the regression coefficient resembles the degree of significance of each variable term in the model [32]. From Equation (4), the main effects B and $\mathrm{D}$, showed their synergistic response on the extraction of $\mathrm{Cd}(\mathrm{II})$. On the other hand, BD interaction term and quadratic $\mathrm{B}^{2}$ and $\mathrm{D}^{2}$, showed antagonism on $\mathrm{Cd}(\mathrm{II})$ extraction. This shows that an increase in Aliquat 336 and EDTA will boost the separation of $\mathrm{Cd}(\mathrm{II})$ over $\mathrm{Cu}(\mathrm{II})$, while their squares and interaction terms will eventually reduce $\mathrm{Cd}(\mathrm{II})$ extraction.

Table 5. Estimated regression coefficients of extraction of Cd(II) using Minitab software; B: Aliquat 336 (mM); D: EDTA (mM).

\begin{tabular}{ccccc}
\hline Term & Coefficient & SD $_{\text {coef }}$ & t-Stat & $p$-Value \\
\hline Constant & 37.994 & 0.953 & 39.88 & $<10^{-4}$ \\
B & 2.3481 & 0.0220 & 106.60 & $<10^{-4}$ \\
D & 1.3097 & 0.0218 & 60.14 & $<10^{-4}$ \\
B*B & -0.012152 & 0.000138 & -88.08 & $<10^{-4}$ \\
D $^{*} \mathrm{D}$ & -0.015325 & 0.000216 & -71.09 & $<10^{-4}$ \\
$\mathrm{~B}^{*} \mathrm{D}$ & -0.001230 & 0.000227 & -5.41 & $<10^{-4}$ \\
\hline
\end{tabular}


The adequacy of the regression model for $\mathrm{Cd}(\mathrm{II})$ extraction was examined using analysis of variance (ANOVA). The $p$-values from the regression model, as in Table 6, were low $(<0.05)$, whereas the linear, square, and interaction terms indicated that they were statistically significant. Prediction on Cd(II) extraction $\%$ was satisfactory by having a high $p$-value of $0.125(>0.05)$, based on the lack-of-fit of the model. $\mathrm{R}^{2}$ value that is 0.998 (close to 1 ), implied that the second-order regression model for Cd(II) extraction was satisfactory.

Table 6. ANOVA of regression model for extraction of Cd(II); B: Aliquat 366 (mM); D: EDTA (mM); DF: degrees of freedom; SS: sum of squares; MS: mean square.

\begin{tabular}{cccccc}
\hline Source & DF & SS & MS & F-Value & $p$-Value \\
\hline Regression & 5 & 2065.85 & 413.171 & 7991.15 & $<10^{-4}$ \\
B (Linear) & 1 & 587.58 & 587.581 & 11364.41 & $<10^{-4}$ \\
D (Linear) & 1 & 186.98 & 186.983 & 3616.45 & $<10^{-4}$ \\
$\mathrm{~B}^{*} \mathrm{~B}$ (Square) & 1 & 401.13 & 401.133 & 7758.32 & $<10^{-4}$ \\
$\mathrm{D}^{*} \mathrm{D}$ (Square) & 1 & 261.27 & 261.275 & 5053.32 & $<10^{-4}$ \\
$\mathrm{~B}^{*} \mathrm{D}$ (Interaction) & 1 & 1.51 & 1.513 & 29.26 & $<10^{-4}$ \\
Residual error & 7 & 0.66 & 0.052 & & \\
Lack-of-fit & 3 & 0.36 & 0,119 & 1.94 & 0.125 \\
Pure error & 4 & 0.30 & 0.001 & & \\
Total & 12 & 2066.52 & & & \\
SD reg & 0.353 & & & & \\
R-squared & 0.998 & & & & \\
\hline
\end{tabular}

\subsubsection{Optimum Conditions for the Extraction of Cd(II) Ions}

Figure 5a showed a 2D response contour plot of Cd(II) extraction versus Aliquat 336 and EDTA in coded unit. It revealed an increase of \% extraction with Aliquat 336 and EDTA, and over $90 \%$ of $\mathrm{Cd}$ (II) extraction was achieved in the region of 70 to $100 \mathrm{mM}$ of Aliquat 336 and 20 to $50 \mathrm{mM}$ EDTA. The corresponding three-dimensional response surface plot in Figure $5 \mathrm{~b}$ also reveals similar conditions for the maximum extraction of $\mathrm{Cd}(\mathrm{II})$.

The optimum conditions of factors in uncoded units (Aliquat $336=99.64 \mathrm{mM}$; EDTA $=48.86 \mathrm{mM}$ ) obtained from the optimization plot of \% extraction of $\mathrm{Cd}(\mathrm{II})$ (Figure 6) generated by the Minitab software with high composite desirability (0.96531).

To maximize the extraction of $\mathrm{Cd}(\mathrm{II})$ from the mixture of $\mathrm{Cd}(\mathrm{II})-\mathrm{Cu}(\mathrm{II})(100 \mathrm{mg} / \mathrm{L})$ synthetic solution, experimental runs were conducted under optimum conditions, whereby, 10 min of mixing time, $99.6 \mathrm{mM}$ Aliquat 336, $50 \mathrm{mM}$ TBP, $48.86 \mathrm{mM}$ EDTA, O:A = 1 and $150 \mathrm{rpm}$ of mixing speed using toluene as diluent. The composite desirability of $0.96531(\sim 1.00)$ was obtained from Minitab software as listed in Table 7, with a small deviation (2.76\%) of the experimental $(95.89 \%)$ from the predicted $(98.61 \%)$ Cd(II) extraction \% revealed that the regression model in Equation (4) was satisfied.

Table 7. Model validation with optimum operating conditions for the extraction of Cd(II).

\begin{tabular}{cccccc}
\hline Composite Desirability & Aliquat 336 (mM) & EDTA (mM) & Predicted E\% & Experimental E\% & \% Deviation \\
\hline 0.96531 & 99.64 & 48.86 & 98.61 & 95.89 & 2.76 \\
\hline
\end{tabular}



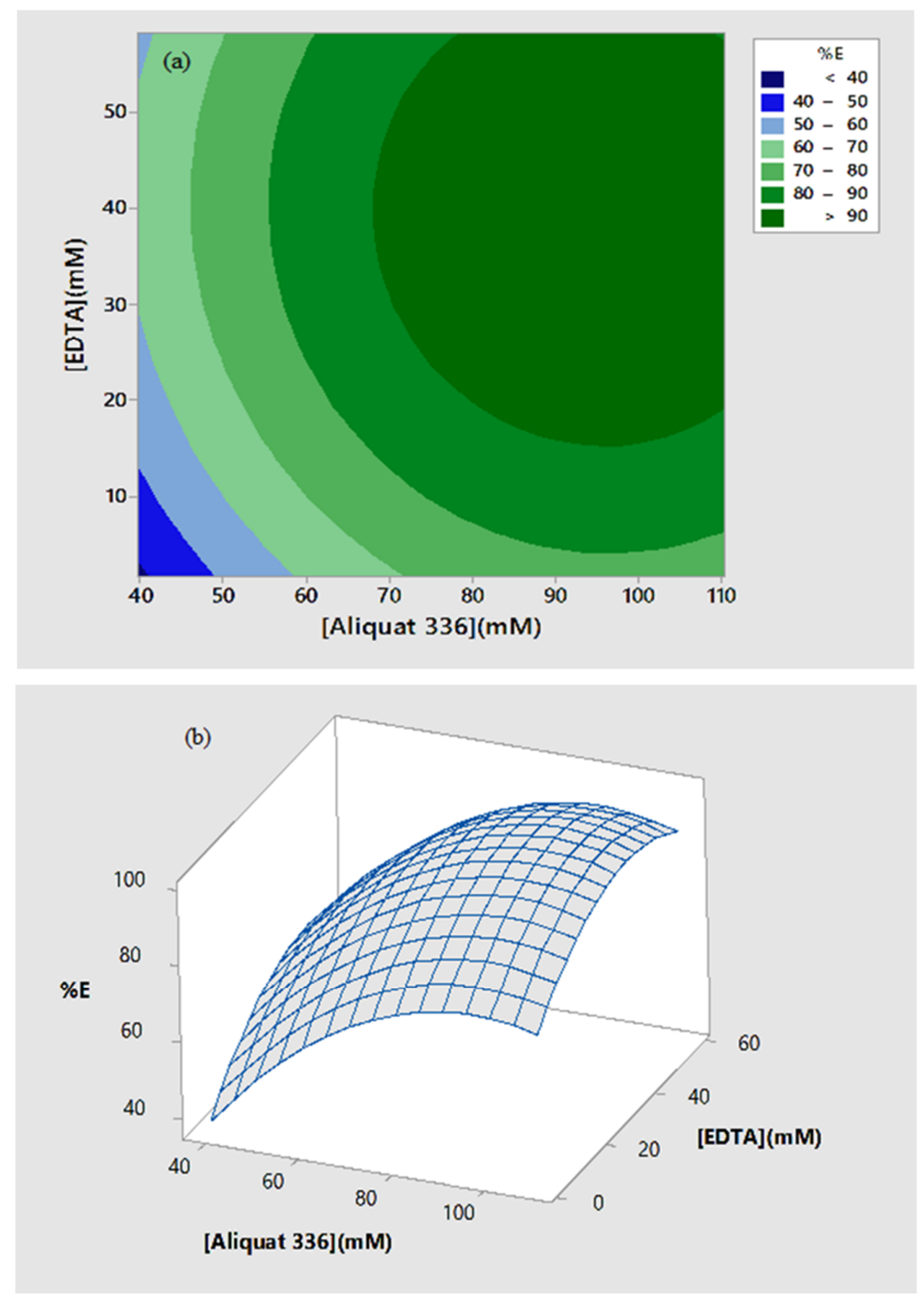

Figure 5. Response surface optimization plots of the extraction of $\mathrm{Cd}(\mathrm{II})$ ions against Aliquat 336 and EDTA in (a) two-dimensional contour plot and (b) three-dimensional response surface plot.

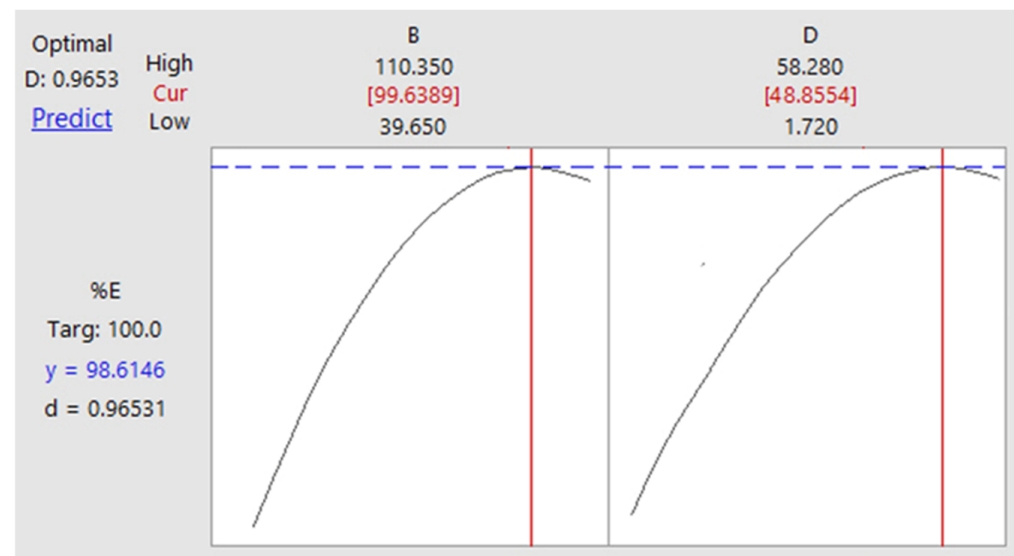

Figure 6. Optimization plot for the extraction of Cd(II) ions; B: Aliquat 336 (mM); D: EDTA (mM). 


\subsection{FTIR Studies}

In this study, FTIR spectroscopy was used to identify the interaction between Aliquat 336 and Cd(II) ions. The infrared spectra of the organic phases with single Aliquat 336 (Figure 7a and the mixtures of Aliquat 336-TBP systems in the absence (Figure 7 and the presence of metals (Figure 7) were recorded. The spectrum of spent Aliquat 336 after stripping was also compared in Figure 7d.

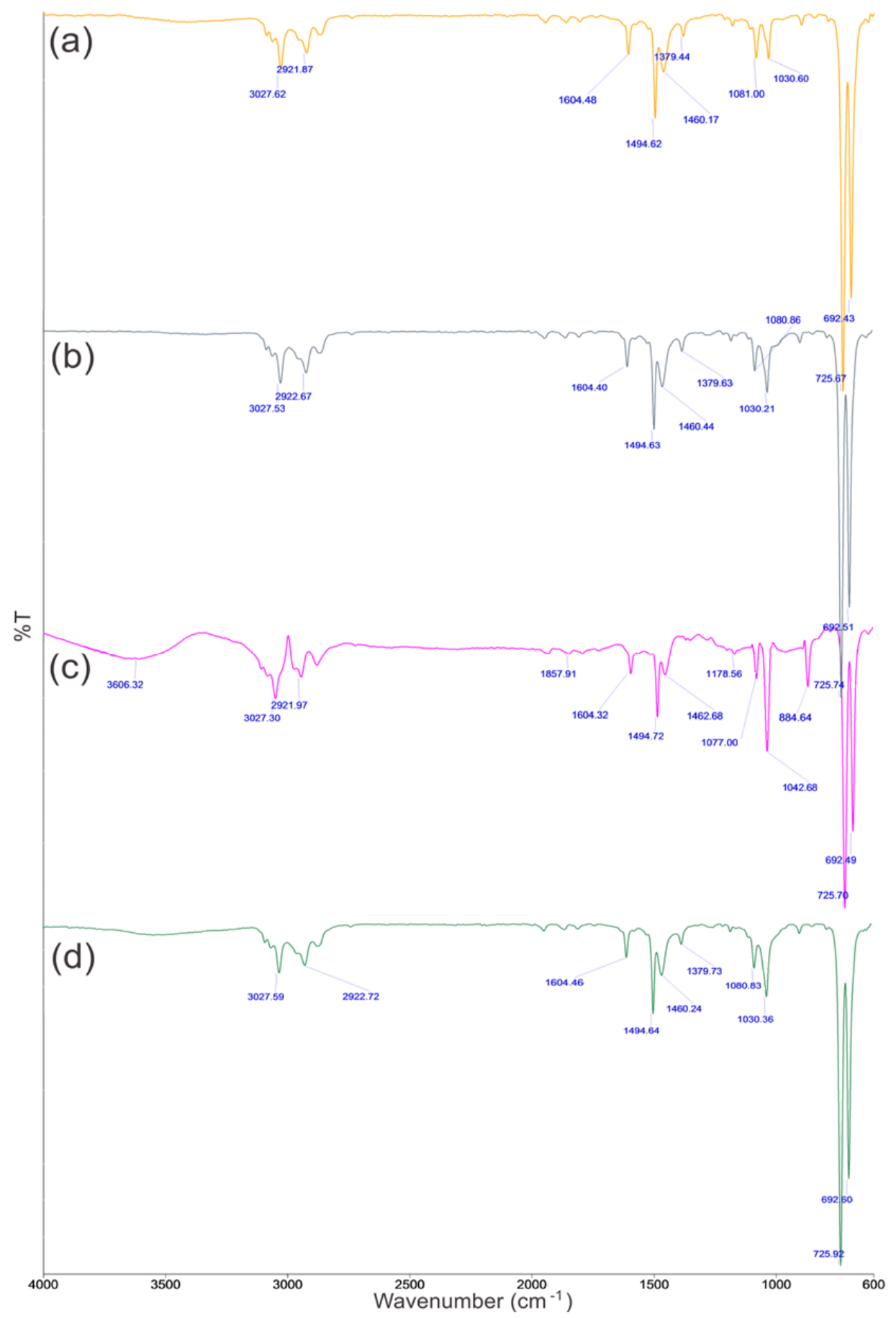

Figure 7. FTIR spectra for (a) Aliquat 336 in toluene, (b) Aliquat 336-TBP in toluene, (c) Cd(II) ions loaded Aliquat 336 and (d) spent Aliquat 336 after stripping.

From Figure 7, the IR spectrum of the Aliquat 336 was almost identical to the spectrum of Aliquat 336-TBP. It confirmed the role of TBP as a phase modifier rather than playing a role as an extractant for 
$\mathrm{Cd}(\mathrm{II})$ ion. By adding TBP, the efficiency of selective extraction increased by causing the separation of $\mathrm{Cd}(\mathrm{II})$ and $\mathrm{Cu}$ (II) isotherm. Consequently, Aliquat 336 plays the main role in Cd extraction. The $-\mathrm{C}-\mathrm{N}$ stretching vibration peak at $1031 \mathrm{~cm}^{-1}$ for Aliquat 336-TBP was shifted to $1043 \mathrm{~cm}^{-1}$ for Cd(II)-Aliquat 336 complex showing that the bonding between $\mathrm{Cd}(\mathrm{II})$ and Aliquat 336 occurred. Stretching of vibration of $-\mathrm{O}-\mathrm{H}$ of soluble water in Aliquat 336-TBP after extraction of $\mathrm{Cd}(\mathrm{II})$ caused the occurrence of a wide adsorption band at $3606 \mathrm{~cm}^{-1}$ for Cd(II)-bonded Aliquat 336-TBP [32]. All four spectra showed the characteristic peak for quaternary amine at the peak of 1460 to $1463 \mathrm{~cm}^{-1}$, were caused by $\left(\mathrm{CH}_{3}\right) \mathrm{N}^{+}$. The asymmetric $-\mathrm{C}-\mathrm{H}$ peaks $\left(2922\right.$ and $3028 \mathrm{~cm}^{-1}$ ) for a mixture of Aliquat 336-TBP before and after extraction studies were similar. The spectrum of spent Aliquat 336 after stripping was almost similar to the fresh Aliquat 336, which confirms the complete stripping of $\mathrm{Cd}(\mathrm{II})$ from the loaded Aliquat 336. A similar finding, by Mishra, et al. [33], also verified the reusability of metal loaded Aliquat 336 after the stripping process.

\section{Conclusions}

Investigation on the addition of phase modifier at different $\mathrm{pH}$ clearly revealed that TBP enhanced the separability of $\mathrm{Cd}$ (II) over $\mathrm{Cu}$ (II) at $\mathrm{pH} 4.5$ to $\mathrm{pH}$ 5.5. The obtained experimental result had proven the possibility of using Aliquat 336 with TBP to selectively separate Cd(II) with high extractability up to $86.37 \%$ over $\mathrm{Cu}(\mathrm{II})(0.59 \%)$ after adding EDTA $(50 \mathrm{mM})$ as a masking agent. Screening of five parameters using a $2^{5-1}$ fractional factorial design, consisted of equilibrium $\mathrm{pH}\left(\mathrm{pH}_{\mathrm{eq}}\right)$, Aliquat 336, TBP, EDTA, and organic to aqueous ratio (O:A) revealed that only Aliquat 336 and EDTA have significantly influenced the selective extraction of $\mathrm{Cd}(\mathrm{II})$ over $\mathrm{Cu}(\mathrm{II})$, followed by optimization with central composite design. A second-order quadratic model was evaluated, and its $\mathrm{R}^{2}$ value (0.998) had proven that the model was highly significant and suitable to predict the extraction of $\mathrm{Cd}(\mathrm{II})$ in the range of variables studied with a deviation error of $2.76 \%$. The optimum operating parameters for maximum separation of Cd(II) over Cu(II) were determined as follows: Aliquat 336 of $99.64 \mathrm{mM}$, TBP of $50 \mathrm{mM}$, EDTA of $48.86 \mathrm{mM}, \mathrm{O}: \mathrm{A}$ of $1, \mathrm{pH}_{\mathrm{eq}}$ of 5, mixing speed of $150 \mathrm{rpm}$, the operating temperature of $28^{\circ} \mathrm{C}$ and mixing time of $10 \mathrm{~min}$. FTIR results have proven that the presence of the interaction between Cd(II) with Aliquat 336. The reusability of Aliquat 336 and its role as the main extractant for extraction of $\mathrm{Cd}(\mathrm{II})$ has been proven.

Author Contributions: Conceptualization, L.Y.L. and N.M.; writing-original draft preparation, L.Y.L. and M.R.; writing-review and editing, N.M., N.I., A.T. and M.R.; supervision, N.M., N.I. and M.R.; funding acquisition, N.M. and M.R. All authors have read and agreed to the published version of the manuscript.

Funding: This work is supported financially by the Ministry of Science, Technology \& Innovation (MOSTI) Malaysia under the MOSTI Research and Development Fund (R\&D Fund) Project No: 03-01-05-SF0847.

Acknowledgments: The authors are grateful to the Universiti Sains Malaysia for supporting and providing the research facilities.

Conflicts of Interest: The authors declare no conflict of interest.

\section{References}

1. Bidari, E.; Irannejad, M.; Gharabaghi, M. Solvent extraction recovery and separation of cadmium and copper from sulphate solution. J. Environ. Chem. Eng. 2013, 1, 1269-1274. [CrossRef]

2. Jha, M.K.; Kumar, V.; Jeong, J.; Lee, J.-C. Review on solvent extraction of cadmium from various solutions. Hydrometallurgy 2012, 111-112, 1-9. [CrossRef]

3. Gotfryd, L.; Cox, M. The selective recovery of cadmium(II) from sulfate solutions by a counter-current extraction-stripping process using a mixture of diisopropylsalicylic acid and Cyanex ${ }^{\circledR} 471 \mathrm{X}$. Hydrometallurgy 2006, 81, 226-233. [CrossRef]

4. Tanong, K.; Tran, L.-H.; Mercier, G.; Blais, J.-F. Recovery of $\mathrm{Zn}(\mathrm{II}), \mathrm{Mn}(\mathrm{II}), \mathrm{Cd}(\mathrm{II})$ and $\mathrm{Ni}(\mathrm{II})$ from the unsorted spent batteries using solvent extraction, electrodeposition and precipitation methods. J. Clean. Prod. 2017, 148, 233-244. [CrossRef] 
5. Vander Hoogerstraete, T.; Onghena, B.; Binnemans, K. Homogeneous Liquid-Liquid Extraction of Rare Earths with the Betaine-Betainium Bis(trifluoromethylsulfonyl)imide Ionic Liquid System. Int. J. Mol. Sci. 2013, 14, 21353-21377. [CrossRef]

6. Mahandra, H.; Singh, R.; Gupta, B. Liquid-liquid extraction studies on Zn(II) and Cd(II) using phosphonium ionic liquid (Cyphos IL 104) and recovery of zinc from zinc plating mud. Sep. Purif. Technol. 2017, 177, 281-292. [CrossRef]

7. Lerum, H.V.; Sand, S.; Eriksen, D.Ø.; Wibetoe, G.; Omtvedt, J.P. Comparison of single-phase and two-phase measurements in extraction, separation and back-extraction of $\mathrm{Cd}, \mathrm{Zn}$ and $\mathrm{Co}$ from a multi-element matrix using Aliquat 336. J. Radioanal. Nucl. Chem. 2020, 324, 1203-1214. [CrossRef]

8. Zhang, L.; Hessel, V.; Peng, J. Liquid-liquid extraction for the separation of Co(II) from Ni(II) with Cyanex 272 using a pilot scale Re-entrance flow microreactor. Chem. Eng. J. 2018, 332, 131-139. [CrossRef]

9. Kumar, V.; Kumar, M.; Jha, M.K.; Jeong, J.; Lee, J.-c. Solvent extraction of cadmium from sulfate solution with di-(2-ethylhexyl) phosphoric acid diluted in kerosene. Hydrometallurgy 2009, 96, 230-234. [CrossRef]

10. Halim, S.F.A.; Chang, S.H.; Morad, N. Extraction of $\mathrm{Cu}(\mathrm{II})$ ions from aqueous solutions by free fatty acid-rich oils as green extractants. J. Water Process. Eng. 2020, 33, 100997. [CrossRef]

11. Flieger, J.; Feder-Kubis, J.; Tatarczak-Michalewska, M. Chiral Ionic Liquids: Structural Diversity, Properties and Applications in Selected Separation Techniques. Int. J. Mol. Sci. 2020, 21, 4253. [CrossRef] [PubMed]

12. Park, J.; Jung, Y.; Kusumah, P.; Lee, J.; Kwon, K.; Lee, C.K. Application of Ionic Liquids in Hydrometallurgy. Int. J. Mol. Sci. 2014, 15, 15320-15343. [CrossRef] [PubMed]

13. Swain, S.S.; Nayak, B.; Devi, N.; Das, S.; Swain, N. Liquid-liquid extraction of cadmium(II) from sulfate medium using phosphonium and ammonium based ionic liquids diluted in kerosene. Hydrometallurgy 2016, 162, 63-70. [CrossRef]

14. Pospiech, B. Studies on extraction and permeation of cadmium(II) using Cyphos IL 104 as selective extractant and ion carrier. Hydrometallurgy 2015, 154, 88-94. [CrossRef]

15. Ghosh, A.; Datta, D.; Uslu, H.; Bamufleh, H.S.; Kumar, S. Separation of copper ion $\left(\mathrm{Cu}^{2+}\right)$ from aqueous solution using tri-n-butyl phosphate and di-2-ethylhexyl phosphoric acid as extractants. J. Mol. Liq. 2018, 258, 147-154. [CrossRef]

16. Chang, S.H.; Teng, T.T.; Ismail, N. Efficiency, stoichiometry and structural studies of Cu(II) removal from aqueous solutions using di-2-ethylhexylphosphoric acid and tributylphosphate diluted in soybean oil. Chem. Eng. J. 2011, 166, 249-255. [CrossRef]

17. Torkaman, R.; Asadollahzadeh, M.; Torab-Mostaedi, M.; Maragheh, M.G. Reactive extraction of cobalt sulfate solution with D2EHPA/TBP extractants in the pilot plant Oldshue-Rushton column. Chem. Eng. Res. Des. 2017, 120, 58-68. [CrossRef]

18. Amani, P.; Asadi, J.; Mohammadi, E.; Akhgar, S.; Esmaili, M. Cooperative influence of D2EHPA and TBP on the reactive extraction of cobalt from sulfuric acid leach solution in a horizontal semi-industrial column. J. Environ. Chem. Eng. 2017, 5, 4716-4727. [CrossRef]

19. Ma, Y.; Wang, X.; Wang, M.; Jiang, C.; Xiang, X.; Zhang, X. Separation of V(IV) and Fe(III) from the acid leach solution of stone coal by D2EHPA/TBP. Hydrometallurgy 2015, 153, 38-45. [CrossRef]

20. Talebi, A.; Teng, T.T.; Alkarkhi, A.F.M.; Norli, I.; Low, L.W. Optimization of nickel removal using liquid-liquid extraction and response surface methodology. Desalin. Water Treat. 2012, 47, 334-340. [CrossRef]

21. Azizitorghabeh, A.; Rashchi, F.; Babakhani, A. Stoichiometry and structural studies of Fe(III) and Zn(II) solvent extraction using D2EHPA/TBP. Sep. Purif. Technol. 2016, 171, 197-205. [CrossRef]

22. Takeshita, K.; Watanabe, K.; Nakano, Y.; Watanabe, M. Solvent extraction separation of Cd(II) and Zn(II) with the organophosphorus extractant D2EHPA and the aqueous nitrogen-donor ligand TPEN. Hydrometallurgy 2003, 70, 63-71. [CrossRef]

23. Sastre, A.M.; Kumar, A.; Shukla, J.P.; Singh, R.K. Improved techniques in liquid membrane separations: An overview. Sep. Purif. Rev. 1998, 27, 213-298. [CrossRef]

24. Czyrski, A.; Jarzębski, H. Response Surface Methodology as a Useful Tool for Evaluation of the Recovery of the Fluoroquinolones from Plasma-The Study on Applicability of Box-Behnken Design, Central Composite Design and Doehlert Design. Processes 2020, 8, 473. [CrossRef]

25. Oyekanmi, A.A.; Ahmad, A.; Hossain, K.; Rafatullah, M. Statistical optimization for adsorption of Rhodamine B dye from aqueous solutions. J. Mol. Liq. 2019, 281, 48-58. [CrossRef] 
26. Altin, S.; Alemdar, S.; Altin, A.; Yildirim, Y. Facilitated transport of Cd(II) through a supported liquid membrane with Aliquat 336 as a carrier. Sep. Sci. Technol. 2011, 46, 754-764. [CrossRef]

27. Lee, L.Y.; Morad, N.; Ismail, N.; Rafatullah, M. Synergistic extraction of Cd, Cu and Ni with D2EHPA/TBP: Screening of factors by fractional factorial design. Int. J. Chem. Eng. Appl. 2019, 10, 114-120. [CrossRef]

28. Myers, R.H.; Montgomery, D.C.; Anderson-Cook, C.M. Response Surface Methodology: Process and Product Optimization Using Designed Experiments, 4th ed.; John Wiley \& Sons, Inc.: New York, NY, USA, 2016.

29. Clever, H.L.; Derrick, M.E.; Johnson, S.A. The solubility of some sparingly soluble salts of zinc and cadmium in water and in aqueous electrolyte solutions. J. Phys. Chem. Ref. Data 1992, 21, 941-1004. [CrossRef]

30. Fatmehsari, D.H.; Darvishi, D.; Etemadi, S.; Hollagh, A.R.E.; Alamdari, E.K.; Salardini, A.A. Interaction between TBP and D2EHPA during $\mathrm{Zn}, \mathrm{Cd}, \mathrm{Mn}, \mathrm{Cu}, \mathrm{Co}$ and Ni solvent extraction: A thermodynamic and empirical approach. Hydrometallurgy 2009, 98, 143-147. [CrossRef]

31. Nayl, A.A. Extraction and separation of $\mathrm{Co}(\mathrm{II})$ and Ni(II) from acidic sulfate solutions using Aliquat 336. J. Hazard. Mater. 2010, 173, 223-230. [CrossRef]

32. Chang, S.H.; Teng, T.T.; Ismail, N.; Alkarkhi, A.F. Selection of design parameters and optimization of operating parameters of soybean oil-based bulk liquid membrane for $\mathrm{Cu}(\mathrm{II})$ removal and recovery from aqueous solutions. J. Hazard. Mater. 2011, 190, 197-204. [CrossRef] [PubMed]

33. Mishra, R.K.; Rout, P.C.; Sarangi, K.; Nathsarma, K.C. Solvent extraction of Fe(III) from the chloride leach liquor of low grade iron ore tailings using Aliquat 336. Hydrometallurgy 2011, 108, 93-99. [CrossRef]

(C) 2020 by the authors. Licensee MDPI, Basel, Switzerland. This article is an open access article distributed under the terms and conditions of the Creative Commons Attribution (CC BY) license (http://creativecommons.org/licenses/by/4.0/). 